\title{
Comparison of Trauma Scoring Systems in Children with Chest Trauma
}

\section{Göğüs Travmalı Çocuklarda Travma Puanlama Sistemlerinin Karşılaştırılması}

İbrahim AYDOĞDU' id , Nuri ŞEN² id, Recep TUNCER ${ }^{3}$ id, Olgaç FAZLI ${ }^{4}$ id, Erbuğ KESKIN ${ }^{5}$ id, Hasan OKUR ${ }^{3}$ id,

Işk OLCAY ${ }^{3}$ id, Ünal ZORLUDEMIR ${ }^{3}$ id

'Department of Pediatric Surgery, Bezmialem Vakif University School of Medicine, İstanbul, Turkey

${ }^{2}$ Department of Pediatric Surgery, Yedikule Surp Pirgic Ermeni Vakfi Hospital, İstanbul, Turkey

${ }^{3}$ Department of Pediatric Surgery, Çukurova University School of Medicine, Adana, Turkey

${ }^{4}$ Department of Pediatric Surgery, Dumlupınar University Evliya Celebi Training and Research Hospital, Kütahya, Turkey

${ }^{5}$ Department of Pediatric Surgery, İstanbul University School of Medicine, İstanbul, Turkey

\section{ABSTRACT}

Objective: This study was conducted to determine the effectiveness of current trauma scoring systems in childhood traumas and to compare these scoring systems with each other.

Methods: In our study, files of 208 patients (age $7.5 \pm 3.7$ years) with chest trauma who have been followed in our clinic and data regarding their sex, age, body weight, cause of trauma, type of trauma, other system injuries, length of stay in hospital, death rate and its reasons were collected, and for each patient Pediatric trauma score (PTS), Injury severity score (ISS), New injury severity score (NISS), Revised trauma score (RTS), Trauma and injury severity score were calculated and relations between the scores were evaluated.

Results: 174 (83.7\%) cases had blunt trauma, 34 (16.3\%) cases had penetrant chest trauma. The most commonly observed pathologies were lung contusion (44.2\%), hemopneumothorax (20.2\%), pneumothorax (18.3\%), diaphragm rupture $(6.2 \%)$ and flail chest $(4.8 \%)$. ISS and NISS were found to be the best scoring systems to determine mortality $(\mathrm{p}=0.0002)$, while RTS was found to be more reliable than PTS in triage.

Conclusion: None of the scoring systems are perfect in thorax traumas. However, we believe that popularization of the use of trauma scoring systems will bring significant advantages to diagnosis and treatment.

Keywords: Pediatric thoracic trauma, pediatric chest trauma, trauma scoring systems, trauma score, triage

\section{öz}

Amaç: $\mathrm{Bu}$ çalışma mevcut travma puanlama sistemlerinin çocukluk çağı toraks travmalarındaki etkinliğinin saptanması ve bu puanlama sistemlerinin birbirleriyle karşılaştırılması amacıyla yapılmıştır.

Yöntemler: Çalışmamızda, kliniğimizde izlenen göğüs travmalı 208 (149 erkek, $59 \mathrm{kız}$, yaş 7.5 \pm 3.7 ) hastanın dosyaları retrospektif olarak cinsiyet, yaş, vücut ağırlıkları, travma nedeni, travma tipi, diğer sistem yaralanmaları, hastanede yatış süresi, ölüm oranı ve nedenlerine ait verileri toplanmış olup her bir hasta için Pediatric trauma score (PTS) (=pediatrik travma puanı (PTP)), Injury severity score (ISS) (=yaralanma şiddet puanı (YŞP)), New injury severity score (NISS) (=yeni yaralanma şiddet puanı (YYŞP)), Revised trauma score (RTS) (=düzeltilmiş travma puanı (DTP)), Trauma and injury severity score (TRISS) (=travma ve yaralanma şiddet puanı (TYŞP)) hesaplanarak puanlar arasındaki ilişkiler değerlendirilmiştir.

Bulgular: Olgulardan 174'ünde künt (\%83,7), 34’ünde ise penetran $(\% 16,3)$ göğus travması mevcuttu. En sık rastlanan patolojiler; akciğer kontüzyonu $(\% 44,2)$, hemopnömotoraks $(\% 20,2)$, pnömotoraks $(\% 18,3)$, diyafram rüptürü (\%6.2) ve yelken göğüstü (\%4.8), YŞP ve YYŞP ölüm oranını belirlemede en iyi skorlama sistemi olarak bulunurken $(\mathrm{p}=0.0002)$, triyajda DTP'nin PTP'ye göre daha güvenilir olduğu saptand.

Sonuç: Toraks travmalarında puanlama sistemlerinin hiçbirisi mükemmel değildir. Fakat travma puanlama sistemlerinin kullanımının yaygınlaştııılmasının tanı ve tedavide önemli avantajlar getireceğini düşünmekteyiz.

Anahtar Kelimeler: Çocuklarda toraks travması, çocuklarda gögüs travması, travma puanlama sistemleri, travma puanı, triyaj

\section{This study was presented at the "Third Congress of Mediterranean Association of Pediatric Surgeons (MAPS)", "12-15 October 2000", "Corfu, Greece" as oral presentation. \\ Bu çalışma "Akdeniz Çocuk Cerrahları Derneği Üçüncü Kongresi", "12-15 Ekim 2000", "Korfu, Yunanistan" sunumunda sözlü olarak sunulmuştur.}

Cite this article as: Aydoğdu i, Şen N, Tuncer R, Fazlı O, Keskin E, Okur H et al. Comparison of Trauma Scoring Systems in Children with Chest Trauma. Bezmialem Science 2018; 6(4): 253-61. 


\section{Introduction}

Trauma is one of the most important causes of childhood death in developed countries. $(1,2)$. Deaths and disabilities caused by trauma related injuries are greater than the sum of all other causes. Chest traumas in children are second in frequency in causing death after head traumas $(3,4)$. Mortality due to chest trauma as a single cause of death is $5 \%$, and this ratio increases up to $25 \%$ along with additional traumatized systems (5). In order to determine regional, national and international importance of childhood trauma, accurate and easily accessible data are needed. These data are needed not only to detect problems and to determine target audience, but also to carry out injury control and treatment strategies in an unbiased and realistic way and to evaluate success of achieving goals.

Trauma scoring systems (TSS) have been developed to reduce mortality rates of children suffering trauma, to shorten duration of hospitalization, to improve quality of patient care, to determine possible survival rates and to reduce hospital expenses (6). Scoring systems for trauma patients have been used for nearly 30 years (7) and these scoring systems have been developed further to improve diagnosis and treatment methods for trauma patients. On the other hand, non-serious trauma patients are referred to advanced health facilities and this leads to unnecessary loss of workforce and an increase in medical expenses.

In this study, we aimed to determine trauma scores of children with chest trauma by examining their records and determining the most appropriate trauma scoring system by comparing scoring systems with each other. So, we thought to contribute to the reduction of mortality rates by providing patients with the fastest and the most appropriate treatment in chest traumas according to their trauma scores, and improving scoring systems by determining possible survivals.

\section{Methods}

This study was conducted by examination of 208 child patients' files retrospectively, who were followed due to chest trauma in the Çukurova University School of Medicine Department of Pediatric Surgery. The study was planned retrospectively and was made in accordance with the Declaration of Helsinki with the decision taken from the Local Ethics Committee. Informed consent was obtained from the patients. We followed the Advanced Trauma Life Support (ATLS $)$ guidelines in our cases. The patients' gender, age, body weight, cause of trauma, type of trauma, duration for admission to our hospital after trauma, lesions on the chest associated with trauma, additional system injuries, complications, length of hospital stay, mortality rate and its causes were examined. For each patient, injury severity score (ISS), new injury severity score (NISS), pediatric trauma score (PTS), revised trauma score (RTS), trauma and injury severity score (TRISS) were calculated and the relationship between the scores were evaluated.
Our patients were divided into three age groups as pre-school ( $0-6$ years old), school age (7-11 years old) and adolescents (1214 years old). The body weights of the children were evaluated in three groups; below $10 \mathrm{~kg}, 10-20 \mathrm{~kg}$ and above $20 \mathrm{~kg}$.

\section{Calculation of Abbreviated Injury Scale (AIS)}

AIS-90 was calculated basically by using AIS-94 (8) versions. According to the severity of injuries the following points were given; 1 point for minor injuries, 2 points for moderate injuries, 3 points for significant injuries, 4 points for severe injuries and 5 points for very severe injuries.

\section{Calculation of Pediatric Glasgow Coma Scale (PGCS)}

In order to evaluate mental status of the children, the points given to the best eye response (1-4 points), the best verbal response (1-5 points) and the best motor response (1-6 points) were added up. PGCS (9) identifies 3 points as the worst state of consciousness and 15 points as the best state of consciousness. The obtained scores were used to calculate RTS.

\section{Calculation of ISS and NISS}

Injuries of six anatomical areas as head-neck, chest, abdomenpelvis, extremity, spine and skin were scored from 1 to 5 according to AIS-90 and AIS-94. It is calculated by summing the square of the highest AIS scores of three anatomic areas at most. NISS was calculated by summing the square of the highest AIS scores irrespective of their anatomical area. The injuries in other anatomic areas and other scores of the area where the scoring was carried out were disregarded. One point represents the best prognosis and 75 points represents the worse prognosis. Patients with an ISS score above 15 were considered to have a major trauma and those with an ISS score below 15 were considered to have a minor trauma.

\section{Calculation of PTS}

Pediatric trauma score was obtained by adding the scores given to a total of six physiological and anatomical parameters as +2 (very minor or no injury), +1 (minor or potential big injury) and -1 (major or life-threatening injury). The lowest score is -6 and it represents the worse prognosis and the highest score is +12 points representing the best prognosis. As death can be seen in those patients with a PTS equal to or below 8 , these patients were considered to have suffered major trauma.

\section{Calculation of RTS}

The following scores were given for respiratory rate; 4 points for those with a respiratory rate of 10-29, 3 points for a respiratory rate above 29,2 points for a respiratory rate between $6-9,1$ point for a respiratory rate between $1-5$, and 0 point for those with no respiration. Four points were given to those with a systolic blood pressure above $89 \mathrm{mmHg}, 3$ points between 76-89, 2 points between 50-75, 1 point between 1-49 and 9 points for those with no blood pressure.

\section{Pediatric Glasgow Coma Scale (PGCS)}

4 points were given for those with a score between 13-15, 3 points between 9-12, 2 points between 6-8, 1 point between 4-5 and 0 point for those with a score equal to or below 3 . 
RTS was obtained by summing the points of these three parameters. RTS varies between $0-12$. Patients with a RTS equal to or below 11 should be considered to have a serious trauma that requires to be followed in a trauma center.

\section{TRISS - Calculation of the Probability of Survival}

Trauma and injury severity score (TRISS) was calculated for two different (blunt and penetrating) trauma types with the following method:

Ps $=1 /\left(1+e^{-b}\right)$

Ps= Probability of survival

$e=2.7183$

$\mathrm{b}=\mathrm{b}_{0}+\mathrm{b}_{1}(\mathrm{RTS})+\mathrm{b}_{2}$ (ISS) $+\mathrm{b}_{3}$ (age index)

Table 1. Gender, age groups, weight, type of trauma, causes of trauma, admitted time and first application center $(n=208)$

\begin{tabular}{|c|c|c|}
\hline & n & $\%$ \\
\hline \multicolumn{3}{|l|}{ Gender } \\
\hline Female & 59 & 28.4 \\
\hline Male & 149 & 71.6 \\
\hline \multicolumn{3}{|l|}{ Age groups } \\
\hline $0-6$ & 93 & 44.7 \\
\hline $7-11$ & 68 & 32.7 \\
\hline $12+$ & 47 & 22.6 \\
\hline \multicolumn{3}{|l|}{ Weight (Kg) } \\
\hline $0-9$ & 5 & 2.5 \\
\hline $10-20$ & 94 & 45.3 \\
\hline $21+$ & 109 & 52.2 \\
\hline \multicolumn{3}{|l|}{ Type of trauma } \\
\hline Blunt & 174 & 83.7 \\
\hline Penetrating & 34 & 16.3 \\
\hline \multicolumn{3}{|l|}{ Causes of trauma } \\
\hline Motor vehicle accidents & 114 & 54.8 \\
\hline Falls & 53 & 25.5 \\
\hline Abuse & 17 & 8.2 \\
\hline Others & 24 & 11.5 \\
\hline \multicolumn{3}{|l|}{ Admitted time } \\
\hline $0-3$ hours & 52 & 25.0 \\
\hline 4-6 hours & 77 & 37.0 \\
\hline 7 hours or later & 49 & 23.6 \\
\hline Unknown & 30 & 14.4 \\
\hline \multicolumn{3}{|l|}{ First application } \\
\hline Our hospital & 61 & 29.3 \\
\hline Another hospital & 147 & 70.7 \\
\hline
\end{tabular}

For blunt traumas;

$b_{0}=-1.2470$

$\mathrm{b}_{1}=0.9544$

$b_{3}=0.9544$

For penetrating traumas;

$\mathrm{b}_{0}=-0.6029$

$\mathrm{b}_{1}=1.1430$

$\mathrm{b}_{3}=-0.1516$

If patients are below 55 , their age index is taken as $\left(b_{3}\right) 0$, if they are above 55 , their age index is taken as 1 . Since our patient group was $0-14$ years old, $b_{3}$ was not taken into consideration and it was taken as 0 .

The Injury severity score, PTS, RTS and AIS scores were calculated separately for each patient and relations between these scores and mortality rates were found.

In statistical analysis, the descriptive statistics were Fisher's Exact test, Student $t$ test, Chi-square test, Spearman Rank Correlation Coefficient (r), logistics recession analysis and linear recession analysis.

The test results $p \leq 0.05$ values were considered significant.

\section{Results}

Out of 208 patients with chest trauma, 149 were male and 59 were female. The average age was found to be 7.5 \pm 3.7 . When we looked at the trauma type, it was determined that 174 patients had blunt trauma while 34 patients had penetrating trauma. Traffic accidents come in first place among trauma causes, followed by falls, assault - use of force and other reasons. After trauma, $25 \%$ of the patients were admitted to the emergency service within the first three hours, $37 \%$ within four-six hours, and $23.6 \%$ of them within seven hours or later. We could not obtain hospitalization information of thirty patients $(14.4 \%)$. Average duration for admission to our hospital is 6.2 hours $(6.2 \pm 0.4)$. Seventy point seven percent $(70.7 \%)$ of these patients applied to another health institution before they were admitted to our hospital (Table 1).

\section{Type of injury and intervention}

Trauma-induced lesions respectively are lung contusions, rib fractures, hemopneumothorax, pneumothorax, traumatic asphyxia, diaphragmatic rupture and flail chest. There were $69(33 \%)$ patients with chest injuries alone, and 139 (67\%) patients with multiple system injuries. Sixty percent of all children with chest trauma receieved conservative treatment, $36.1 \%$ chest tube, $6.2 \%$ laparotomy, $4.8 \%$ thoracentesis and $3.4 \%$ thoracotomy. Only 14 patients $(6.7 \%)$ had atelectasis, pneumonia, empyema or developed complications related to chest tube. 


\section{Causes of death}

It was reported that $23(11.1 \%)$ patients died. The causes of death respectively are head trauma, respiratory failure, hypovolemic shock and cardiac tamponade (Table 2).

The average length of stay of our patients was 7.1 days (7.1 \pm 7.1$)$. Patients with only chest trauma had shorter hospital stay as compared to those with other system injuries in addition to chest trauma $(\mathrm{p}=0.006)$. While average hospital stay for children who died was 2.9 days, the average stay for patients who survived was 7.6 days $(\mathrm{p}=0.002)$. The length of hospital stay of those who applied to another health institution after trauma was longer than those who did not $(\mathrm{p}=0.01)$. Girls had a shorter stay in the hospital compared to boys $(\mathrm{p}=0.03)$.

Average and standard deviation of our patients' ISS, NISS, PTS, RTS and TRISS scores are given in Table 3.

Accordingly, PTS revealed significant differences based on whether or not there are chest injuries alone or additional system injuries, whether or not it was applied to another health institution after trauma, the cause of trauma, trauma type, age groups and result of the patients. In RTS, ISS and NISS, on the other hand, significant differences were obtained according to chest trauma alone or additional system injuries, cause of trauma, trauma type and results (Table 4). TRISS revealed

Table 2. Mortality rate and causes of death

\begin{tabular}{|l|c|c|c|}
\hline Result & & & \\
Survived & 185 & 88.9 \\
\hline Died & 23 & 11.1 \\
\hline Cause of death & & \\
\hline Head trauma & 14 & 60.9 \\
\hline Respiratory failure & 4 & 17.4 \\
\hline Hypovolemic shock & 4 & 17.4 \\
\hline Cardiac tamponade & 1 & 4.3 \\
\hline
\end{tabular}

Table 3. Average and standard deviation of TSSs

\begin{tabular}{lcc|} 
& Average & sd \\
\hline PTS & 7.3 & 3.0 \\
RTS & 9.6 & 1.9 \\
ISS & 21.4 & 13.3 \\
NISS & 24.1 & 14.5 \\
TRISS-B & 86.6 & 24.3 \\
TRISS-P & 97.4 & 6.4 \\
\hline TSS: trauma scoring systems; PTS: pediatric trauma score; RTS: revised \\
trauma score; ISS: injury severity score; NISS: new injury severity score; \\
TRISS-B: trauma and injury severity score-blunt; TRISS-P: trauma and \\
injury severity score-penetrating; sd:standard deviation
\end{tabular}

a significant difference, in terms of their survival rates, between patients with blunt traumas with chest injury alone and patients with blunt traumas with additional system injuries $(\mathrm{p}=0.000)$. TRISS revealed a significant difference, in terms of their survival rates, between patients with penetrating traumas with chest injury alone and patients with penetrating traumas with additional system injuries $(\mathrm{p}=0.03)$.

\section{Relationship between trauma associated lesions and aver-} age possible survival, PTS, RTS, ISS and LOS

The mortality rate of the patients in our series due to chest trauma, PTS, RTS, ISS and average length of their hospital stay and probability of survivals (Ps) are shown in Table 5. It was determined that although flail chest incidence is the lowest, it has the highest mortality rate. In terms of high mortality rates it is followed by hemothorax, traumatic asphyxia and lung contusion respectively.

Lesions in this table were prepared only by taking into consideration chest injuries. Head injuries and other similar injuries were not included in this table. While some of the patients also had additional system injuries, also multiple chest injuries (flail chest, hemopneumothorax, lung contusion, etc.) were found in a single patient. No mortality was observed in any of the patients with an ISS lower than 21. Mortality rates increased with the patients with an ISS bigger than 19 in parallel to the increase in the scores. While mortality was observed in all six patients with a PTS equal to or below 0 $(100 \%)$, mortality decreases as the score increases. Two of 27 (6.8\%) patients with a PTS that was equal to 9 died, mortality rates of those patients with PTS above 9 were zero. All eight patients with a RTS below and equal to 5 died (100\%). Mortality rate of the patients with a score of six or higher decreases as their score increases. Mortality is zero with a score of eleven or higher (Table 6-8).

\section{Discussion}

Thoracic traumas affect other systems due to having an effect on vital organs and deterioration of oxygenation, and are one of the major causes of deaths associated with trauma, especially in the childhood period $(1,10)$. In many studies a consensus was reached that the limit value of ISS is 15 (2, 11). In their study, Peclet et al. (12) calculated ISS average as 26.7 and reported mortality rate as $26 \%$. In our series, the average ISS is 21.4 . The fact that the ISS average of survivors is 19 while it is 40.3 for the deceased patients shows that our patients generally suffered serious traumas. In our study, the average ISS of the chest traumas caused by motor vehicle accidents is 25.2 and 17 due to falls. There is a significant difference between the ISS values of penetrating trauma $(13.3 \pm 7.8)$ and blunt trauma $(23.0 \pm 13.5)$. The average ISS of our $34 \mathrm{pa}-$ tients who suffered penetrating chest trauma is 13.3 and mortality rate is $2.9 \%$. In the studies, the ISS of blunt traumas is higher than that of penetrating traumas $(13,14)$. When it is remembered that motor vehicle accidents are the most frequent cause of blunt traumas and of injuries in more than 
one system generally, it is obvious that it will have a higher ISS than penetrating traumas.

Injury severity score values that are below or equal to 15 represent minor trauma, those that are above 15 represent major trauma (11, 12). While death is not expected for scores below limit value, mortality can be seen, increasing in proportion to scores above limit value $(14,15)$. In our study, the ISS of $71(34.1 \%)$ patients was below and equal to 15 . While $45(63.3 \%)$ of these patients applied to another health institutions previously, 26 (36.7\%) of them directly applied to the pediatric emergency room of our hospital.
Eichelberger et al. (16) argued that the ISS of the majority of children is below 20 and the limit value should be taken as 19 points. When the limit value is taken as 15 points for dead patients, the ISS's sensitivity is $100 \%$ and specificity is $38.3 \%$. When the limit value is accepted as 19, the ISS sensitivity is $100 \%$ and specificity is $55.6 \%$. This means that when the ISS limit value is 19 , it identified all (100\%) of the patients who died due to severe trauma and $55.6 \%$ of the patients with no severe trauma (Table 6).

The values we obtained in our study showed compatibility with the study of Eichelberger at al. (16) and ISS limit value

Table 4. Average and standard deviation values of TSSs in terms of parameters

\begin{tabular}{|c|c|c|c|c|c|c|}
\hline & PTS & RTS & ISS & NISS & TRISS-B & TRISS-P \\
\hline \multicolumn{7}{|l|}{ Gender } \\
\hline Female & $7.1 \pm 3.4$ & $9.5 \pm 1.9$ & $21.6 \pm 14.3$ & $24.6 \pm 15.6$ & $84.3 \pm 27.8$ & $95.4 \pm 8.9$ \\
\hline Male & $7.4 \pm 2.8$ & $9.7 \pm 1.9$ & $21.3 \pm 12.8$ & $24.0 \pm 14.1$ & $87.5 \pm 22.7$ & $97.9 \pm 5.7$ \\
\hline$p$ & 0.4 & 0.6 & 0.9 & 0.7 & 0.4 & 0.3 \\
\hline \multicolumn{7}{|l|}{ Age group } \\
\hline $0-6$ & $6.7 \pm 3.1$ & $9.5 \pm 1.7$ & $21.2 \pm 12.2$ & $24.2 \pm 13.6$ & $88.1 \pm 23.3$ & $99.2 \pm 0.9$ \\
\hline $7-11$ & $8.1 \pm 2.5$ & $9.7 \pm 2.2$ & $20.5 \pm 14.0$ & $23.2 \pm 15.4$ & $85.9 \pm 25.8$ & $95.5 \pm 9.6$ \\
\hline $12+$ & $7.4 \pm 3.2$ & $9.8 \pm 1.7$ & $23.1 \pm 14.1$ & $25.4 \pm 15.2$ & $83.8 \pm 24.8$ & $98.3 \pm 2.7$ \\
\hline$p$ & 0.009 & 0.7 & 0.5 & 0.7 & 0.6 & 0.3 \\
\hline \multicolumn{7}{|l|}{ Type of trauma } \\
\hline Blunt & $7.0 \pm 3.1$ & $9.5 \pm 2.0$ & $23.0 \pm 13.5$ & $25.8 \pm 14.6$ & $86.6 \pm 24.3$ & - \\
\hline Perforating & $9.1 \pm 1.7$ & $10.2 \pm 0.7$ & $13.3 \pm 7.8$ & $15.5 \pm 10.7$ & - & $97.4 \pm 6.4$ \\
\hline p & 0.000 & 0.05 & 0.000 & 0.000 & & \\
\hline \multicolumn{7}{|l|}{ Cause of trauma } \\
\hline Motor vehicle accident & $6.5 \pm 3.2$ & $9.3 \pm 2.3$ & $25.2 \pm 13.4$ & $28.1 \pm 14.0$ & $83.4 \pm 27.4$ & - \\
\hline Falls & $8.4 \pm 2.5$ & $10.0 \pm 1.1$ & $17.0 \pm 13.3$ & $19.5 \pm 15.4$ & $92.1 \pm 16.8$ & $99.7 \pm 0.2$ \\
\hline Others & $8.2 \pm 2.3$ & $10.1 \pm 0.8$ & $16.5 \pm 8.8$ & $19.2 \pm 11.4$ & $94.9 \pm 6.4$ & $96.9 \pm 6.9$ \\
\hline$p$ & 0.000 & 0.007 & 0.000 & 0.000 & 0.05 & 0.3 \\
\hline \multicolumn{7}{|c|}{ Applied to another health institution } \\
\hline Yes & $7.1 \pm 3.0$ & $9.6 \pm 1.8$ & $22.4 \pm 12.3$ & $25.4 \pm 13.5$ & $86.7 \pm 23.1$ & $96.8 \pm 7.6$ \\
\hline No & $8.0 \pm 2.9$ & $9.7 \pm 2.1$ & $19.0 \pm 15.0$ & $23.2 \pm 16.4$ & $86.3 \pm 27.2$ & $98.7 \pm 1.2$ \\
\hline \multicolumn{7}{|l|}{ Isolated or Additional } \\
\hline Isolated chest & $9.0 \pm 1.9$ & $10.5 \pm 0.8$ & $10.5 \pm 6.0$ & $13.1 \pm 9.5$ & $98.5 \pm 1.6$ & $99.2 \pm 0.6$ \\
\hline Chest + Additional system & $6.5 \pm 3.1$ & $9.2 \pm 2.1$ & $26.8 \pm 12.5$ & $29.1 \pm 12.3$ & $82.0 \pm 27.2$ & $94.3 \pm 9.9$ \\
\hline$p$ & 0.000 & 0.000 & 0.000 & 0.000 & 0.000 & 0.03 \\
\hline \multicolumn{7}{|l|}{ Result } \\
\hline Survived & $7.9 \pm 2.3$ & $10.1 \pm 0.9$ & $19.0 \pm 11.4$ & $21.5 \pm 12.6$ & $94.1 \pm 9.4$ & $98.0 \pm 5.2$ \\
\hline Died & $2.8 \pm 4.1$ & $5.7 \pm 3.0$ & $40.3 \pm 11.7$ & $45.3 \pm 11.9$ & $34.6 \pm 31.7$ & $75.3 \pm$ \\
\hline$p$ & 0.000 & 0.000 & 0.000 & 0.000 & 0.000 & 0.000 \\
\hline
\end{tabular}


Table 5. Relationship between trauma associated lesions and average probability of survival, PTS, RTS, ISS and length of hospital stay

\begin{tabular}{|c|c|c|c|c|c|c|c|}
\hline & n (\%) & $\begin{array}{c}\text { Dead rate } \\
(\%)\end{array}$ & $\begin{array}{c}\text { Average } \\
\text { Ps }\end{array}$ & $\begin{array}{c}\text { Average } \\
\text { PTS }\end{array}$ & $\begin{array}{c}\text { Average } \\
\text { RTS }\end{array}$ & $\begin{array}{c}\text { Average } \\
\text { ISS }\end{array}$ & $\begin{array}{c}\text { Average } \\
\text { LOS }\end{array}$ \\
\hline Pulmonary contusion & $92(44.2)$ & 16.3 & .82 & 6.3 & 9.2 & 26.6 & 7.4 \\
\hline Rib fracture & $76(36.5)$ & 12.7 & .86 & 6.5 & 9.6 & 26.0 & 8.6 \\
\hline Hemopneumothorax & $42(20.2)$ & 9.5 & .92 & 7.3 & 9.9 & 23.1 & 9.3 \\
\hline Pneumothorax & $38(18.3)$ & 5.3 & .86 & 6.6 & 9.3 & 26.1 & 8.5 \\
\hline Hemothorax & 29 (13.9) & 20.7 & .81 & 6.7 & 9.2 & 23.4 & 11.8 \\
\hline Traumatic asphyxia & $25(12.0)$ & 20.0 & .77 & 5.4 & 8.5 & 27.6 & 9.2 \\
\hline Diaphragm rupture & $13(6.2)$ & 7.6 & .90 & 7.5 & 9.7 & 18.9 & 10.5 \\
\hline Flail chest & $10(4.8)$ & 40.0 & .69 & 5.2 & 8.5 & 32.7 & 5.2 \\
\hline
\end{tabular}

Table 6. According to the mortality of patients, sensitivity, specificity, positive and negative determining values of identified limit values of RTS, PTS and ISS

\begin{tabular}{|c|c|c|c|c|c|}
\hline & \multicolumn{5}{|c|}{ Death } \\
\hline & \multicolumn{2}{|c|}{ RTS } & \multirow{2}{*}{$\begin{array}{l}\text { PTS } \\
(>8)\end{array}$} & \multicolumn{2}{|c|}{ ISS } \\
\hline & $(>10)$ & $(>11)$ & & $(>15)$ & $(>19)$ \\
\hline Sensitivity & 100.0 & 100.0 & 91.3 & 100.0 & 100.0 \\
\hline Specificity & 34.1 & 5.4 & 43.7 & 38.3 & 55.6 \\
\hline Positive determining value & 100.0 & 100.0 & 97.6 & 100.0 & 100.0 \\
\hline Negative determining value & 15.8 & 11.6 & 16.8 & 16.8 & 21.9 \\
\hline
\end{tabular}

Table 7. According to the ISS score identified with two different limit values (ISS>15, ISS>19), determination of triage limits of other scoring systems

\begin{tabular}{|c|c|c|c|c|}
\hline & \multicolumn{2}{|c|}{ ISS>15 } & \multicolumn{2}{|c|}{ ISS> 19} \\
\hline & Specificity & Sensitivity & Specificity & Sensitivity \\
\hline \multicolumn{5}{|l|}{ TS } \\
\hline 11 & 11.2 & 98.5 & 8.1 & 99.0 \\
\hline $10 *$ & 43.2 & 84.5 & 45.6 & 84.7 \\
\hline 9 & 98.5 & 39.5 & 95.1 & 43.8 \\
\hline 8 & 100.0 & 19.7 & 99.0 & 24.7 \\
\hline \multicolumn{5}{|c|}{ PTS } \\
\hline 9 & 57.7 & 89.0 & 46.6 & 92.7 \\
\hline $8 x$ & 74.6 & 78.1 & 63.1 & 82.8 \\
\hline 7 & 81.6 & 58.3 & 74.7 & 53.8 \\
\hline & $\begin{array}{l}\text { I values for Is } \\
\text { y severity sc } \\
\text { core }\end{array}$ & $\begin{array}{l}\text {, xoptimal v } \\
\text { TS: revised }\end{array}$ & $\begin{array}{l}\text { for ISS>19 } \\
\text { ta score; PTS }\end{array}$ & diatric \\
\hline
\end{tabular}

was determined as 19. None of our patients with an ISS below 21 died. When the ISS limit value was considered as 19, 69 (66.9\%) out of 103 (49.5\%) patients with an ISS score below
Table 8. Sensitivity, specificity, positive and negative determining values of triage limit values defined for RTS and PTS



\begin{tabular}{|c|c|c|c|c|}
\hline Sensitivity & 84.5 & 78.1 & 84.7 & 82.2 \\
\hline Specificity & 43.2 & 74.6 & 45.6 & 63.1 \\
\hline $\begin{array}{l}\text { Positive } \\
\text { determining value }\end{array}$ & 56.5 & 85.6 & 61.3 & 69.6 \\
\hline $\begin{array}{l}\text { Negative } \\
\text { determining value }\end{array}$ & 76.1 & 63.8 & 74.6 & 78.3 \\
\hline False negative & 25.0 & 30.0 & 15.0 & 18.0 \\
\hline False positive & 34.0 & 18.0 & 56.0 & 38.0 \\
\hline
\end{tabular}

this value applied to another health institution, 34 (33.1\%) of them applied to our emergency room directly. When patients' gender, age groups and whether or not they applied to another health institution after trauma were compared to each other, there was no statistically significant difference in the ISS. 
According to linear regression analysis, it was observed that the relationship between ISS and PTS was more powerful than the relationship between ISS and RTS.

While there was no relationship between children who died and the length of their hospital stay in ISS, there was a significant relationship between children who survived and the length of their hospital stay. In our study, since there is a strong relationship between NISS and ISS statistically, only an ISS evaluation was conducted.

The average PTS of our patients is $7.3(7.3 \pm 3.0)$. The average PTS of our patients who survived is 7.9 and that of those who died is 2.8. No deaths occurred in the patients with a PTS that was above or equal to 10 . In contrast, all of our patients with a PTS that was below and equal to 0 died. In the study conducted by Eichelberger at al. (16), it was determined that the PTS 8 in ISS 15 had a sensitivity of $78 \%$ and a specificity of $75 \%$; while in ISS 19 had a sensitivity of $87 \%$ and specificity of $73 \%$. In our study, when the limit values were taken as 15 and 19, the PTS limit value of all patients was found to be 8 (a sensitivity of 78.1 and specificity of 74.6 in ISS 15 ; a sensitivity of 82.8 and a specificity of 63.1 in ISS 19) (Table 7).

In terms of patients who died, when the PTS limit value is 8 its sensitivity goes up to 91.3 and its specificity reduces to 43.7. Our results show similarity to the results of Eichelberger at al. (16). Balık at al. (17) reported that three patients in their series died although their PTS was above and equal to 9, and one of the patients had intra-abdominal bleeding and two of them had head trauma. Saladino at al. (18) reported that PTS was inadequate in children with liver or spleen injury only.

In our series, our two patients who had a PTS of 9 and died had head trauma and also weight percentile of these patients was below $25 \%$. The weight percentile in developing countries shows a difference, based on malnutrition, as compared to developed countries. Trauma scoring systems, on the other hand, are planned according to the people of developed countries. Therefore, when scores given according to body weight in PTS is given according to weight percentile (if below 25 percentile -1 , between $25-50+1$, above 50 percentile +2 ), then the PTS scores of our two patients who died would reduce to 8 and below. In this way the score would indicate that these patients had major trauma and death is a possibility.

A significant correlation was found between PTS and age. Nine patients out of 93 who were in the group of zero-six year olds $(9.6 \%), 8$ patients out of 68 patients who were in the group of 7-11 year olds (11.7\%) and 6 of 47 patients who were in the group of 12 year olds and above (12.7\%) died. In terms of PTS, although there was a statistically significant difference between pre-school period and children of other age groups, no difference was detected in mortality rates. When it is taken into consideration that the body weights of the majority of these pre-school children were below $20 \mathrm{~kg}$ (in this case PTS will be +1 or -1 for body weight), it becomes evident why the average PTS of these children were lower. The average PTS of the children with only chest trauma was 9, the PTS of the children with one or more system injuries in addition to chest trauma was 6.5 (Table 4). The average PTS is 6.5 for traffic accident, 8.4 for falls and 8.2 for other reasons. When traffic accidents, falls and other reasons are compared individually, there was a statistically significant difference in PTS. The average PTS in blunt traumas is 7 and in penetrating traumas it is 9.1. The average PTS of the patients who applied to another health institution after trauma is 7.1 while the average of those who directly came to our hospital is 8 .

In our study, an inverse relationship was found between PTS and ISS with linear regression analysis method $(\mathrm{r}=-0.63)$. While it was $r=-0.67$ in the study of Nayduch at al. (19), this relationship was found as $r=-0.74$ in the study of Kaufmann at al. (20).

While there is no relation in PTS between the children who died and the length of hospital stay, a significant relation was observed between the children who survived and the length of hospital stay.

The average RTS of our patients is $9.6(9.6 \pm 1.9)$. While the average RTS of those who survived is 10.1, it is 5.7 for those who died. None of the 6 patients with a RTS above or equal to 11 died. While one of the 94 patients with a RTS equal to 10 died, all of the eight patients with a RTS below or equal to five died. The lower the RTS values, the higher the mortality rates. The average RTS for traumas caused by motor vehicle accidents is 9.3, while the average RTS for traumas due to falls and other reasons is 10 and 10.1 (Table 4). The average RTS of blunt traumas is 9.5 and the average RTS of penetrating traumas is 10.2. While the average RTS is 10.5 for the patients with chest trauma only, it is 9.2 for the patients who have additional system injuries.

Patients with a RTS below or equal to 11 are considered to have suffered major trauma and they need to be referred to a trauma center $(16,20,21)$. In our study the triage limit value of RTS was determined as 10 when the ISS value was taken as 15 and 19 . When the ISS is taken as 15 , the RTS's limit value sensitivity is 84.5 and its specificity is 43.2 . When the ISS is taken as 19, the RTS's sensitivity is 84.7 and specificity is 45.6. When the limit value of the RTS in the patients who died was taken as 10 , its sensitivity rises up to 100 , while its specificity reduces down to 34.1 (Table 6).

In the study conducted by Kaufmann et al. (20) where they compared RTS and PTS, they showed it as a disadvantage that the RTS contained only three parameters while PTS contained six parameters and for this reason they argued that RTS's implementation was easier than PTS. They reported that PTS has a significant superiority to RTS. However, when it is taken into consideration that PGCS offers 15 different options under three main headings and that evaluation of mental status of children is difficult, it is revealed that RTS 
is not an easily implementable system as compared to PTS. Eichelberger et al. (16) argued that there was not a significant difference between RTS and PTS, and both can be optionally implemented.

In our study, a significant relationship was detected between RTS and PTS in the linear regression analysis. The inverse relationship of RTS with ISS is lower than the inverse relationship of PTS with ISS.

When Spearman Rank Correlation Coefficients test was applied, a significant relationship between RTS and PGCS was detected. While there was no relationship in the patients who died between RTS and length of hospital stay, an inverse relationship was detected for those patients who survived. When triage limit value of RTS is taken as 10 for ISS 15 , inaccurate negatives are 25 and inaccurate positives are 34; and when it is taken as 8 , inaccurate negatives are 30 and inaccurate positives are 18 (Table 8).

When traumas were compared according to being blunt or penetrating and TRISS survival percentages were compared in terms of age; it was found that the potential survival rates of blunt traumas were lower and the average age was 7.1; the survival rates were higher in penetrating traumas and the average was 9.3. These findings are compatible with other studies (12).

As in all scoring systems, although TRISS has been primarily developed for adult patients, it was shown that it can also be safely used for children (22-24). While the average TRISS for our patients with blunt trauma is 86.6 , it is 97.4 for penetrating traumas. Twenty two of our patients died as a result of blunt trauma, only one patient died as a result of penetrating trauma. So, we can say that the 75.3 average of TRISS-P of only one patient who died as a result of penetrating trauma does not have much significance.

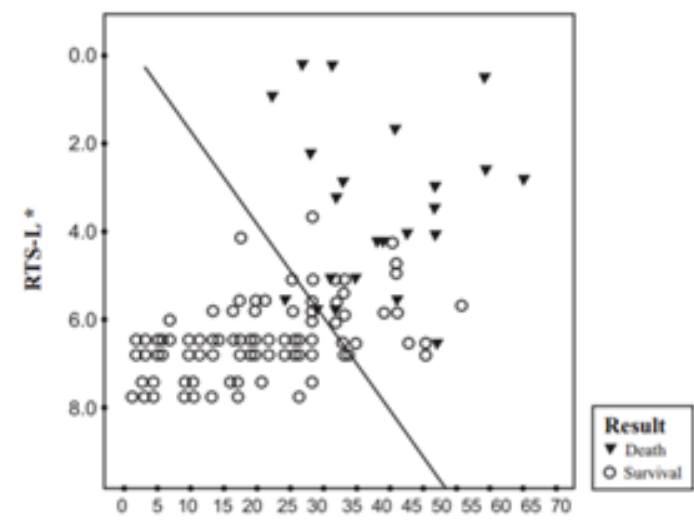

ISS

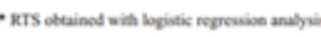

Figure 1 . TRISS profile of our patients
In Figure 1, an unexpected death of one patient under survival line 50 was seen, and unexpected survivals observed in 18 patients. These data are compatible with studies of other trauma centers $(12,22,23)$.

In light of all these data, the ISS limit value was determined as 19 , and at the same value the PTS limit value was found to be 8 and RTS's as 10. As a result of logistic regression analysis where ISS, PTS RTS were included, while a significant relationship was observed between ISS and RTS possible survival estimates, no association between PTS and survival was detected. This situation suggests that ISS is the best estimate factor giving us the best information regarding survival of a child. ISS is calculated in hospital conditions after determining lesions of children who experienced trauma. The fact that 103 (49.5\%) children with a ISS below or equal to 19, which represents minor trauma, were referred to our clinic providing a service quality of a trauma center (two thirds of these patients applied to another health institution after trauma) suggests that the physicians who made the initial evaluation were inadequate in terms of traumas.

In our study, although RTS is superior to PTS in terms of determining triage, it is a fact that there is no significant difference. This situation shows that both scoring systems can be safely used for triage depending on the user's choice. Among the systems that are used today, ISS is the best scoring system that predicts the length of hospital stay of the patients who survive. ISS and NISS do not have superiority to each other. Although RTS was found to be the best system in determining triage, PTS can also be safely applied to trauma patients. In our study, trauma scoring systems based on ISS, PTS and RTS values were found to be important measurement tools to determine triage of patients, ensuring that they receive appropriate treatment in an appropriate place quickly.

The results show that widespread of the use of TSS in our hospital as well as other healthcare facilities will bring significant advantages for trauma victims and healthcare professionals working in this field.

\section{Conclusion}

No scoring system is perfect in terms of evaluation of children with chest trauma. However, with data obtained from trauma children, scoring systems with higher sensitivity and specificity can be developed in the future.

Ethics Committee Approval: Ethics committee approval was received for this study from the ethics committee of Çukurova University School of Medicine (99052-2000).

Informed Consent: Written informed consent was obtained from patients or the parents of the patients who participated in this study.

Peer-review: Externally peer-reviewed. 
Author Contributions: Concept - İ.A., R.T., Ü.Z.; Design - İ.A., R.T., I.O.; Supervision - İ.A., R.T., O.F., E.K.; Data Collection and/ or Processing - İ.A., N.Ş., E.K.; Analysis and/or Interpretation - İ.A., R.T., E.K., I.O.; Literature Search - İ.A.; Writing Manuscript - İ.A.; Critical Review - R.T., E.K., Ü.Z., I.O.

Conflict of Interest: The authors have no conflict of interest to declare.

Financial Disclosure: The authors declared that this study has received no financial support.

Etik Komite Onayı: Bu çalışma için etik komite onayı Çukurova Üniversite'sinden (99052/2000) alınmıştır.

Hasta Onamı: Yazılı hasta onamı bu çalışmaya katılan hastalardan ya da hastaların ailelerinden alınmıștır.

\section{Hakem Değerlendirmesi: Dış bağımsız.}

Yazar Katkıları: Fikir - İ.A., R.T., Ü.Z.; Tasarım - İ.A., R.T., I.O.; Denetleme - İ.A., R.T., O.F.; Veri Toplanması ve/veya İşlemesi - İ.A., N.Ş., E.K.; Analiz ve/veya Yorum - İ.A., R.T., E.K., I.O.; Literatür Taraması - İ.A.; Yazıyı Yazan - İ.A.; Eleştirel İnceleme - R.T., E.K., Ü.Z., I.O.

Çıkar Çatışması: Yazarlar çıkar çatışması bildirmemişlerdir.

Finansal Destek: Yazarlar bu çalışma için finansal destek almadıklarını beyan etmişlerdir.

\section{References}

1. Sturm JA, Pape HC, Dienstknecht T. Trauma care in Germany: an inclusive system. Clin Orthop Relat Res 2013; 471: 291223. [CrossRef]

2. McCarthy A, Curtis K, Holland AJ. Paediatric trauma systems and their impact on the health outcomes of severely injured children: An integrative review. Injury 2016; 47: 574-85. [CrossRef]

3. Sharma M, Lahoti BK, Khandelwal G, Mathur RK, Sharma SS, Laddha A. Epidemiological trends of pediatric trauma: A single-center study of 791 patients. J Indian Assoc Pediatr Surg 2011; 16: 88-92. [CrossRef]

4. Wesson DE, Cox SC Jr. Thoracic injuries. In: Coran AG, Adzick NS, Krummel TM, Laberge JM, Shamberger RC, Caldamone AA, editors. Pediatric Surgery. 7th ed. Philadelphia: Elsevier Saunders; 2012.p.271-87. [CrossRef]

5. Domini M, Carlini V, Lima M. Thoracic trauma. In: Lima M, editor. Pediatric Thoracic Surgery. 1st ed. Milan: Springer-Verlag Italia; 2013.p.381-90. [CrossRef]

6. Guzzo JL, Bochicchio GV, Napolitano LM, Malone DL, Meyer W, Scalea TM. Prediction of outcomes in trauma: anatomic or physiologic parameters? J Am Coll Surg 2005; 201: 891-7. [CrossRef]

7. Esme H, Solak O, Yurumez Y, Yavuz Y, Terzi Y, Sezer M, et al. The prognostic importance of trauma scoring systems for blunt thoracic trauma. Thorac Cardiovasc Surg 2007; 55: 190-5. [CrossRef]
8. Moore EE, Malangoni MA, Cogbill TH, Shackford SR, Champion HR, Jurkovich GJ, et al. Organ injury scaling. IV: Thoracic vascular, lung, cardiac, and diaphragm. J Trauma 1994; 36: 299-300. [CrossRef]

9. Raimondi AJ, Hirschauer J. Head injury in the infant and toddler. Coma scoring and outcome scale. Childs Brain 1984; 11: 12-35.

10. Veysi VT, Nikolaou VS, Paliobeis C, Efstathopoulos N, Giannoudis PV. Prevalence of chest trauma, associated injuries and mortality: a level I trauma centre experience. Int Orthop 2009; 33: 1425-33. [CrossRef]

11. Lecky F, Woodford M, Edwards A, Bouamra O, Coats T. Trauma scoring systems and databases. Br J Anaesth 2014; 113: 286-94. [CrossRef]

12. Peclet MH, Newman KD, Eichelberger MR, Gotschall CS, Garcia VF, Bowman LM. Thoracic trauma in children: an indicator of increased mortality. J Pediatr Surg 1990; 25: 961-5 [CrossRef]

13. Tepas JJ 3rd ${ }^{1}$, Ramenofsky ML, Mollitt DL, Gans BM, DiScala C. The Pediatric Trauma Score as a predictor of injury severity: an objective assessment. J Trauma 1988; 28: 425-9. [CrossRef]

14. Roux $P^{1}$, Fisher RM. Chest injuries in children: an analysis of 100 cases of blunt chest trauma from motor vehicle accidents. J Pediatr Surg 1992; 27: 551-5. [CrossRef]

15. Meller JL, Little AG, Shermeta DW. Thoracic trauma in children. Pediatrics 1984; 74: 813-9.

16. Eichelberger $\mathrm{MR}^{1}$, Gotschall CS, Sacco WJ, Bowman LM, Mangubat EA, Lowenstein AD. A comparison of the trauma score, the revised trauma score, and the pediatric trauma score. Ann Emerg Med 1989; 18: 1053-8. [CrossRef]

17. Balık E, Özok G, Ulman İ, Demircan M, Sakallı Ü. Pediatric trauma score: Is it reliable in predicting mortality? Pediatr Surg Int 1993; 8: 54-5 [CrossRef]

18. Saladino $\mathrm{R}^{1}$, Lund $\mathrm{D}$, Fleisher G. The spectrum of liver and spleen injuries in children: failure of the pediatric trauma score and clinical signs to predict isolated injuries. Ann Emerg Med 1991; 20: 636-40. [CrossRef]

19. Nayduch DA ${ }^{1}$, Moylan J, Rutledge R, Baker CC, Meredith W, Thomason M, et al. Comparison of the ability of adult and pediatric trauma scores to predict pediatric outcome following major trauma. J Trauma 1991; 31: 452-7. [CrossRef]

20. Kaufmann $\mathrm{CR}^{1}$, Maier RV, Rivara FP, Carrico CJ. Evaluation of the Pediatric Trauma Score. JAMA 1990; 263: 69-72. [CrossRef]

21. Mohyuddin GR, Alam Z, Malik UZ, Shakil O, ul Haq A. Revised trauma score as a predictor of outcome in trauma cases: experiences at a tertiary care hospital in Karachi, Pakistan. J Ayub Med Coll Abbottabad 2015; 27: 584-6.

22. Eichelberger $M^{1}$, Champion HR, Sacco WJ, Gotschall CS, Copes WS, Bowman LM. Pediatric coefficients for TRISS analysis. J Trauma 1993; 34: 319-22. [CrossRef]

23. Kaufmann $\mathrm{CR}^{1}$, Maier RV, Kaufmann EJ, Rivara FP, Carrico CJ. Validity of applying adult TRISS analysis to injured children. J Trauma 1991; 31: 691-7. [CrossRef]

24. Orliaguet $\mathrm{G}^{1}$, Meyer P, Blanot S, Schmautz E, Charron B, Riou $\mathrm{B}$, et al. Validity of applying TRISS analysis to paediatric blunt trauma patients managed in a French paediatric level I trauma centre. Intensive Care Med 2001; 27: 743-50. [CrossRef] 